\title{
Marine Algae Collected during the Scientific Expedition to Bachok, Kelantan and the Islands of Terengganu with One New Record, Pterocladiella for Malaysia
}

\author{
Siew-Moi Phang ${ }^{1,}$, Phaik-Eem Lim ${ }^{1,2}$, Hui-Yin Yeong ${ }^{2,3,4}$, Woan-Shien Ng $^{1,2}$ and Sze- \\ Looi Song ${ }^{1,2}$
}

${ }^{1}$ Institute of Biological Sciences, Faculty of Science, ${ }^{2}$ Institute of Ocean \& Earth Sciences, ${ }^{3}$ Institute of Graduate Studies, University of Malaya, 50603 Kuala Lumpur, Malaysia.

${ }^{4}$ Tropical Forest Biodiversity Centre, Forest Research Institute of Malaysia, 52109 Kepong, Selangor Darul Ehsan.

*phang@um.edu.my (corresponding author)

Received on $22^{\text {nd }}$ June 2009, accepted in revised form $30^{\text {th }}$ September 2009.

\begin{abstract}
In 2008, a scientific expedition to Bachok (the new Marine Station), Kelantan and the vicinity of Terengganu, was organised by the Institute of Ocean and Earth Sciences (IOES), University of Malaya. The objective of the expedition was to collect and document the natural resources of Bachok and its vicinity. Our team collected and identified the marine algae resources of the area. A total of 133 taxa of marine algae and four taxa of seagrasses were compiled from the results as well as previous records for Kelantan and Terengganu. The marine algae comprise 3 families of Cyanophyta with 4 genera and 4 taxa; 10 families of Chlorophyta with 13 genera and 35 taxa; 16 families of Rhodophyta with 38 genera and 63 taxa; 4 families of Phaeophyta with 8 genera and 31 taxa. Only 35 taxa were collected during this present survey, the most from the Rhodophyta (14 taxa) followed by the Phaeophyta (12 taxa), the Chlorophyta ( 8 taxa) and the Cyanophyta (4 taxa). Of these, the Cyanophyta Lyngbya, Oscillatoria, Microcoleus and Brachytrichia; the Chlorophyta Ulva compressa, Ulva flexuosa, Ulva intestinalis, Caulerpa serrulata var. boryana; the Rhodophyta Gelidiella acerosa, Gelidium pusillum, Actinotrichia fragilis, Acanthophora spicifera; and the Phaeophyta Dictyota ciliolata, Lobophora variegata, Padina antillarum, Hormophysa cuneiformis and Turbinaria conoides are new records for Kelantan and Terengganu. The Rhodophyta Pterocladiella is a new record for Malaysia. Two families of seagrasses with 3 genera and 4 taxa were collected and included in this checklist. A new species of Halophila will be studied further.
\end{abstract}

\begin{abstract}
ABSTRAK Pada tahun 2008, Institut Sains Samudera dan Bumi (IOES) Universiti Malaya telah melancarkan satu ekspedisi saintifik ke Bachok (Stesen Marin Baru), Kelantan dan dikawasan persekitaran Terengganu. Objektif ekspedisi ini adalah untuk mengutip dan mendokumentasikan sumber semula jadi Bachok dan kawasan sekelilingnya. Kumpulan kami telah mengutip dan mengenal-pasti rumpair laut di kawasan tersebut. Sejumlah 133 takson rumpair laut dan empat takson rumput laut telah dikumpul rekod lama untuk kawasan Kelantan dan Terengganu. Rumpair laut terkandung 3 famili Cyanophyta 4 genera dan 4 takson; 10 famili Chlorophyta 13 genus dan 35 takson; 16 famili Rhodophyta 38 genus dan 63 takson; 4 famili Phaeophyta dengan 8 genus dan 31 takson. Hanya 35 takson telah dikumpulkan daripada ekspedisi ini. Kebanyakan adalah daripada Rhodophyta (14 takson), diikuti oleh Phaeophyta (12 takson), Chlorophyta (8 takson) dan Cyanophyta (4 takson). Cyanophyta Lyngbya, Oscillatoria, Microcoleus dan Brachytrichia; Chlorophyta Ulva compressa, Ulva flexuosa, Ulva intestinalis, Caulerpa serrulata var. boryana; Rhodophyta Gelidiella acerosa, Gelidium pusillum, Actinotrichia fragilis, Acanthophora spicifera; serta Phaeophyta Dictyota ciliolata, Lobophora variegata, Padina antillarum, Hormophysa cuneiformis dan Turbinaria conoides merupakan rekod baru bagi Kelantan dan Terengganu. Rhodophyta Pterocladiella merupakan rekod baru Malaysia. Dua famili rumput laut dengan 3 genus dan 4 takson telah dikutip dan ditambah ke senarai semak ini. Satu species baru Halophila akan dikaji dengan selanjutnya.
\end{abstract}

(Keywords: marine algae, checklist, Bachok, Setiu Wetlands, Pulau Rawa, Pulau Perhentian)

\section{INTRODUCTION}

In 2008, a scientific expedition was organised by the Institute of Ocean and Earth Sciences (IOES), University of Malaya to Bachok, the site of the new Marine Station of the institute. Bachok is situated in Malaysia's most northeastern state of Kelantan and faces the South China Sea. Off the coastline in the vicinity of Bachok are several islands belonging to the neighbouring state of Terengganu; namely Pulau Perhentian Kecil, Pulau Perhentian Besar, Pulau Redang, Pulau Lang Tengah, Pulau Bidong Laut and Pulau Kapas. The objective of the expedition was to 
collect and document the natural resources of Bachok and its vicinity. The specific objective of our research team was to survey and document the marine algae resources of the area. Several of the islands in the vicinity have been gazetted as Marine Parks. Fishing is a major activity in this area while tourism to the island resorts brings in much revenue to the states of Terengganu and Kelantan. The waters surrounding the islands of Redang and Perhentian are pristine, with coral reefs and the associated flora and fauna.

The first major checklist of the marine algae of Malaysia was published by Phang (1998) who recorded two hundred and sixty specific and infraspecific taxa (17 Cyanophyta, 92 Chlorophyta, 94 Rhodophyta and 57 Phaeophyta). A survey (19951999) on the systematics of Malaysian marine algae conducted by the University of Malaya in collaboration with Hokkaido University, Japan, resulted in many additions to the checklist. The present tally includes 386 taxa comprising Chlorophyta (13 families, 102 taxa), Rhodophyta (27 families, 182 taxa), Phaeophyta (8 families, 85 taxa) and Cyanophyta (8 families, 17 taxa) (Phang 2006, Phang et al. 2007). Sixty-six taxa were reported for Pulau Jarak, Sembilan Group of Islands and Pulau Perak, northwest coast of Peninsular Malaysia (Phang et al. 2008a). In 2008 (b), Phang et al. also published a revised checklist of marine algae from the Pulau Tioman group of islands. The checklist comprised 3 taxa of Cyanophyta, 36 taxa of Chlorophyta, 40 taxa of Rhodophyta and 19 taxa of Phaeophyta. Four new records were reported: Dictyosphaeria versluysii Weber-van Bosse from Kampung Mukut, Actinotrichia fragilis (Forsskal) Boergesen from Tanjung Layar, Jania rubens (Linnaeus) Lamouroux from Tanjung Layar and Coelothrix Boergesen from Teluk Tekek.

\section{MATERIALS AND METHODS}

This report is a result of two collection trips carried out simultaneously from 15 till 18 June 2008; one focusing along the coastline starting from north of Bachok, Kelantan, southwards along the coastline of Terengganu down to the Setiu Wetlands; and the second on the islands nearest to Bachok (Figure 1). The locations sampled in Kelantan were Sungai Kemasin, Bachok; Sungai Melawi, Bachok; Tok Bali Jetty; Kuala Semarak, Sungai Semarak and Tumpat. Locations sampled in Terengganu were Pulau Perhentian Besar, Pulau Perhentian Kecil, Pulau Rawa, Kampung Penarik, Setiu; Pantai Bari, Setiu and the Setiu Wetlands. Habitats, from which the algae were collected, include mud, coral, sandy and rocky shores, mangrove, driftweed, wood, fish cage and epiphytes (Figures 2-7). Collection was sparse along the coastline with more samples collected in Terengganu than Bachok. The samples were collected by snorkelling around the islands and by scrapping off substrata like rocks and dead corals. All specimens were cleaned and processed into herbarium, or preserved in formalin for further examination back in the laboratory. The specimens were identified based on morphological and anatomical characteristics, using published keys and taxonomic papers. All specimens are deposited in the University of Malaya Seaweeds and Seagrasses Herbarium. A checklist was prepared from the list of identified specimens from this survey as well as from published records (Phang et al. 2007). Included in this checklist are four seagrasses including a possible new species of seagrass.

\section{RESULTS AND DISCUSSION}

A preliminary checklist (Table 1) with a total of 133 taxa of marine algae and four taxa of seagrasses was compiled from the results as well as previous records for Kelantan and Terengganu. The marine algae comprise 3 families of Cyanophyta with 4 genera and 4 taxa; 10 families of Chlorophyta with 13 genera and 35 taxa; 16 families of Rhodophyta with 38 genera and 63 taxa; 4 families of Phaeophyta with 8 genera and 31 taxa. Of these, only 35 taxa were collected during this present survey, the most from the Rhodophyta (14 taxa) followed by the Phaeophyta (12 taxa), the Chlorophyta (8 taxa) and the Cyanophyta (4 taxa). Of these, the Cyanophyta Lyngbya, Oscillatoria, Microcoleus and Brachytrichia; the Chlorophyta Ulva compressa, Ulva flexuosa, Ulva intestinalis, Caulerpa serrulata var. boryana; the Rhodophyta Gelidiella acerosa, Gelidium pusillum, Actinotrichia fragilis, Acanthophora spicifera; and the Phaeophyta Dictyota ciliolata, Lobophora variegata, Padina antillarum, Hormophysa cuneiformis and Turbinaria conoides are new records for Kelantan and Terengganu. The Rhodophyta Pterocladiella is a new record for Malaysia. Figures 8-20 show some of the species collected and identified.

Two families of seagrasses with 3 genera and 4 taxa were collected and included in this checklist. A new species of Halophila will be studied further. Figures 21-23 show some of the seagrasses collected and identified. 


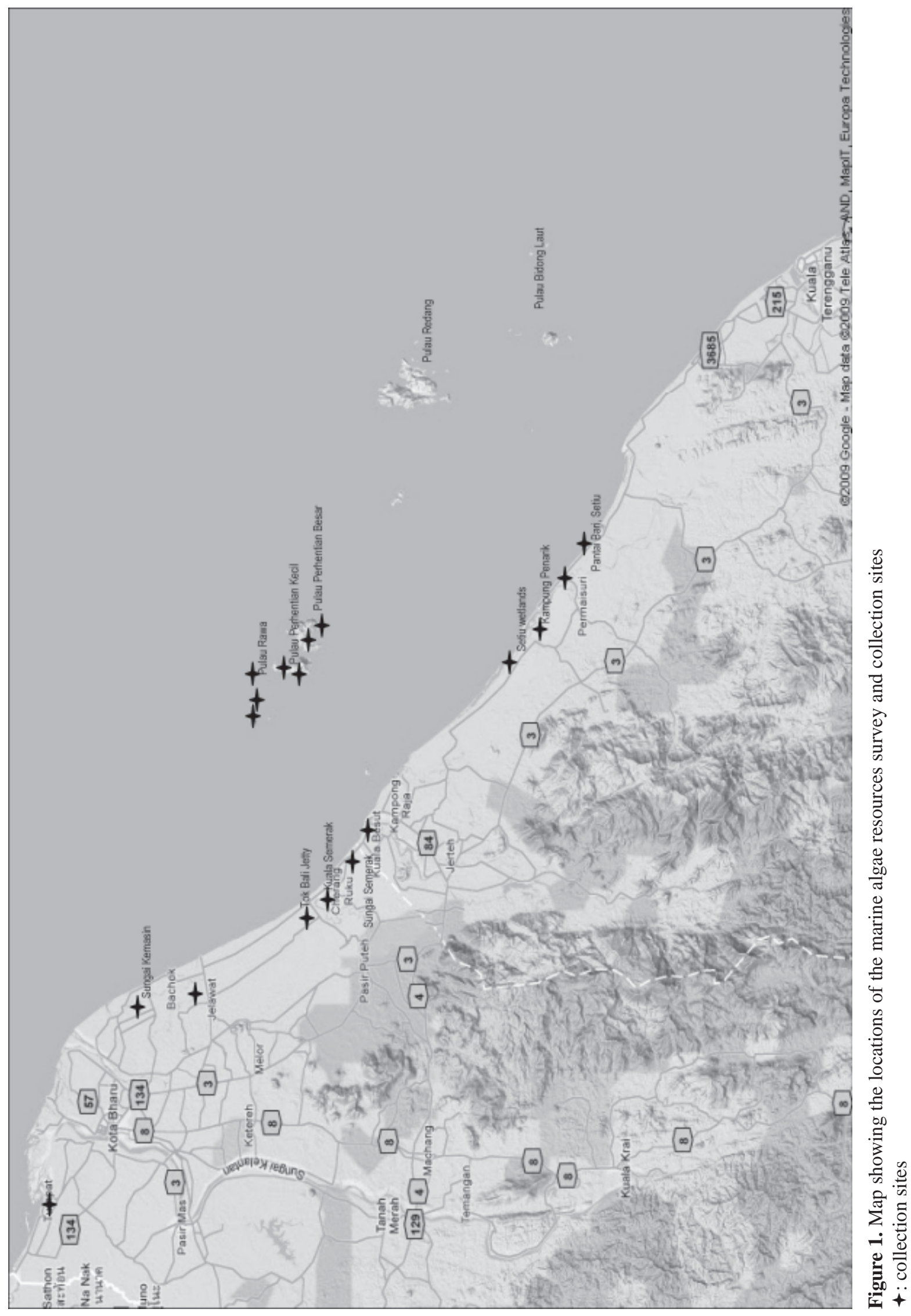




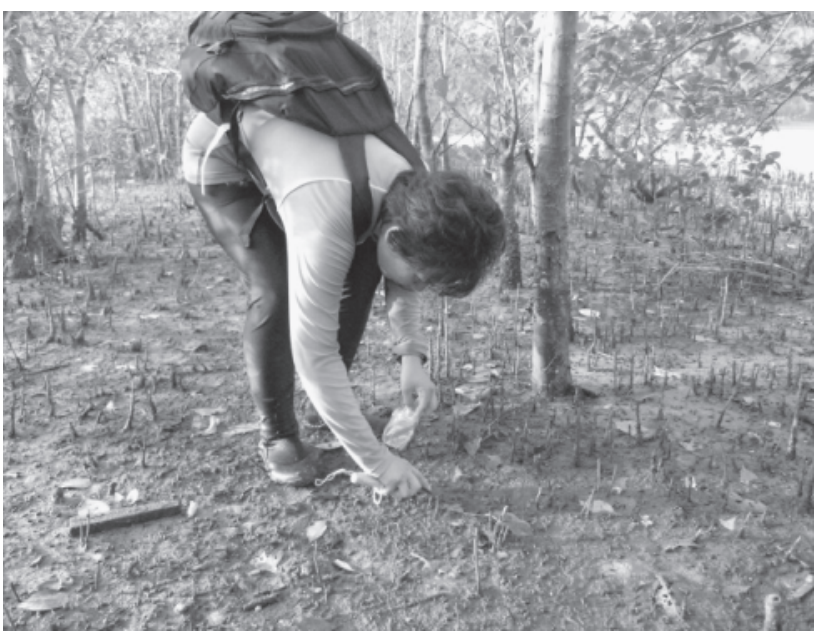

Figure 2. Collecting Chaetomorpha in the mangrove at Kuala Semarak, Kelantan.

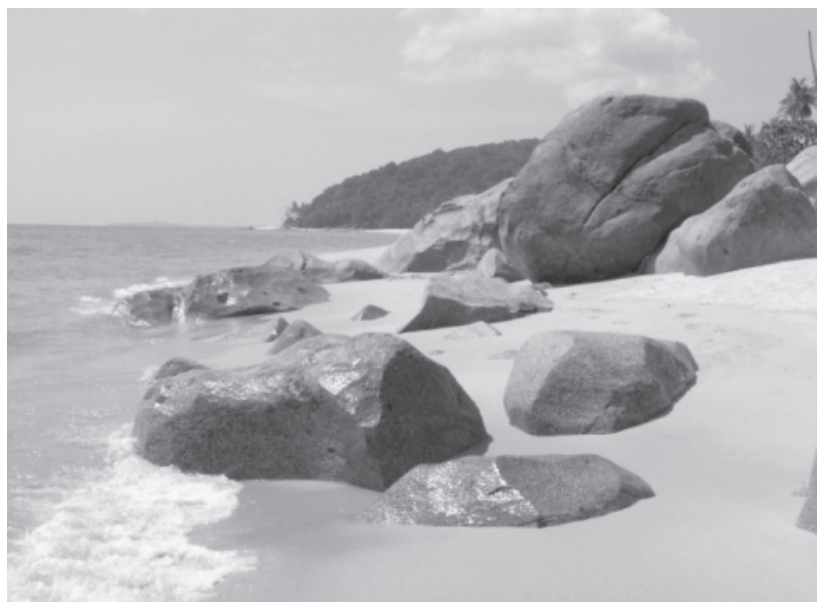

Figure 4. Rocky shore at Pantai Bari, Setiu, Terengganu.

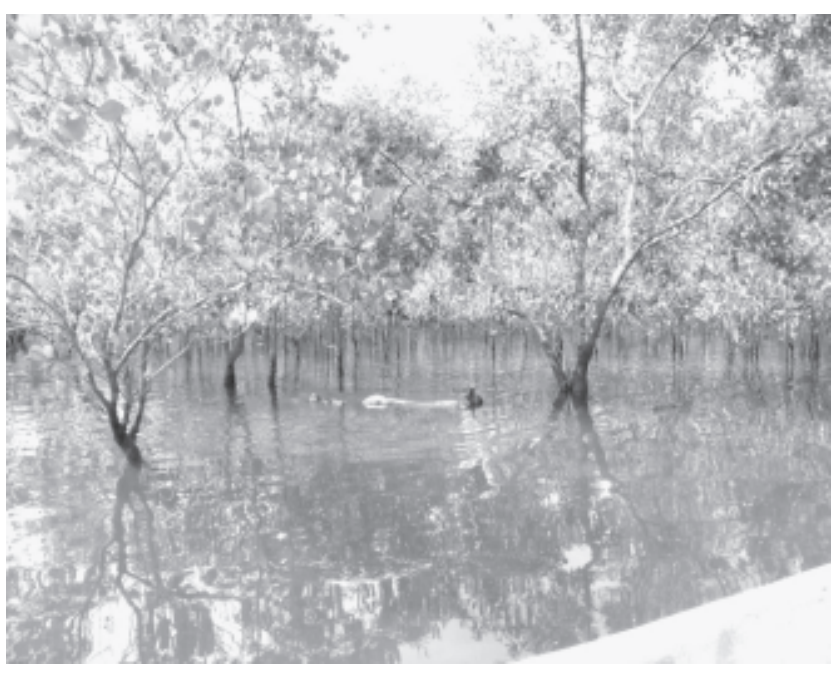

Figure 6. Collecting seaweeds by snorkeling at the mangroves, Sungai Semarak, Kelantan

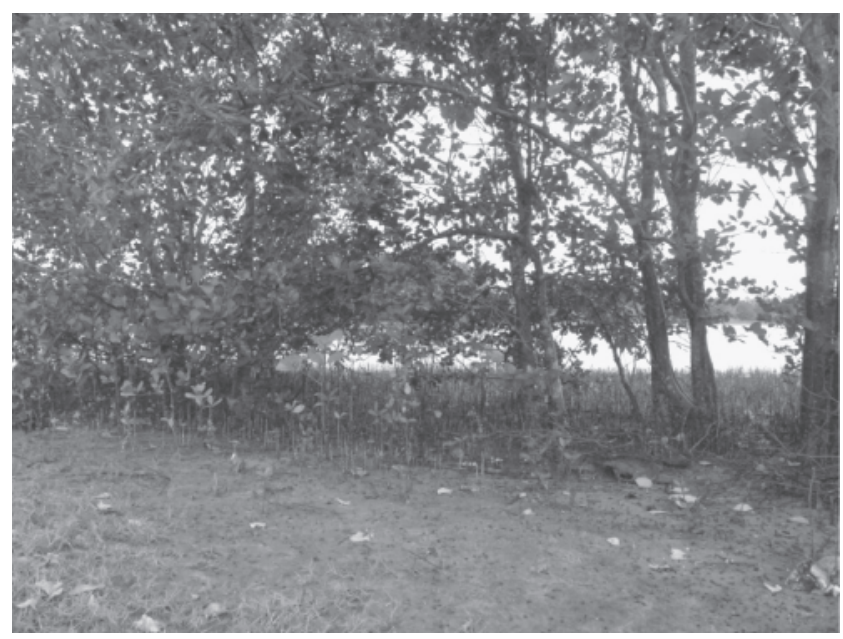

Figure 3. Mangrove in Kuala Semarak at low tide showing abundant growth of Chaetomorpha.

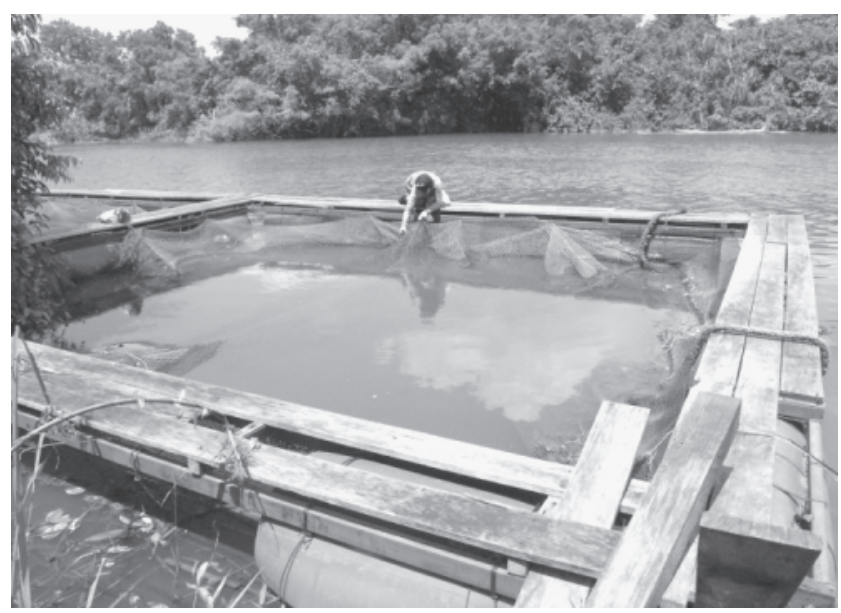

Figure 5. Collecting seaweeds at abandoned fish cages at Kampung Beris Tok Ku, Setiu, Terengganu.

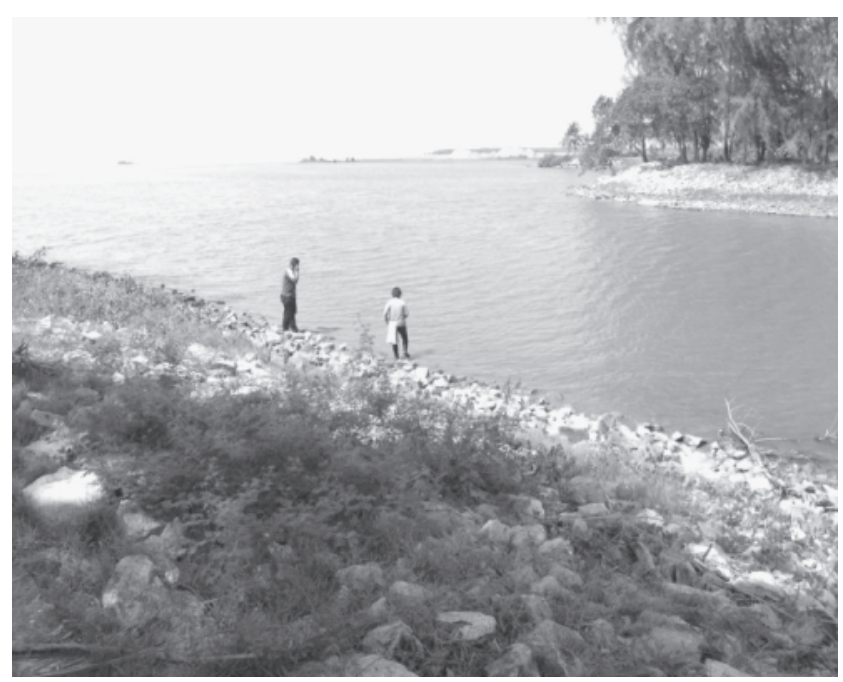

Figure 7. Collecting seagrass at the Pantai Sri Tujuh, Tumpat, Kelantan 


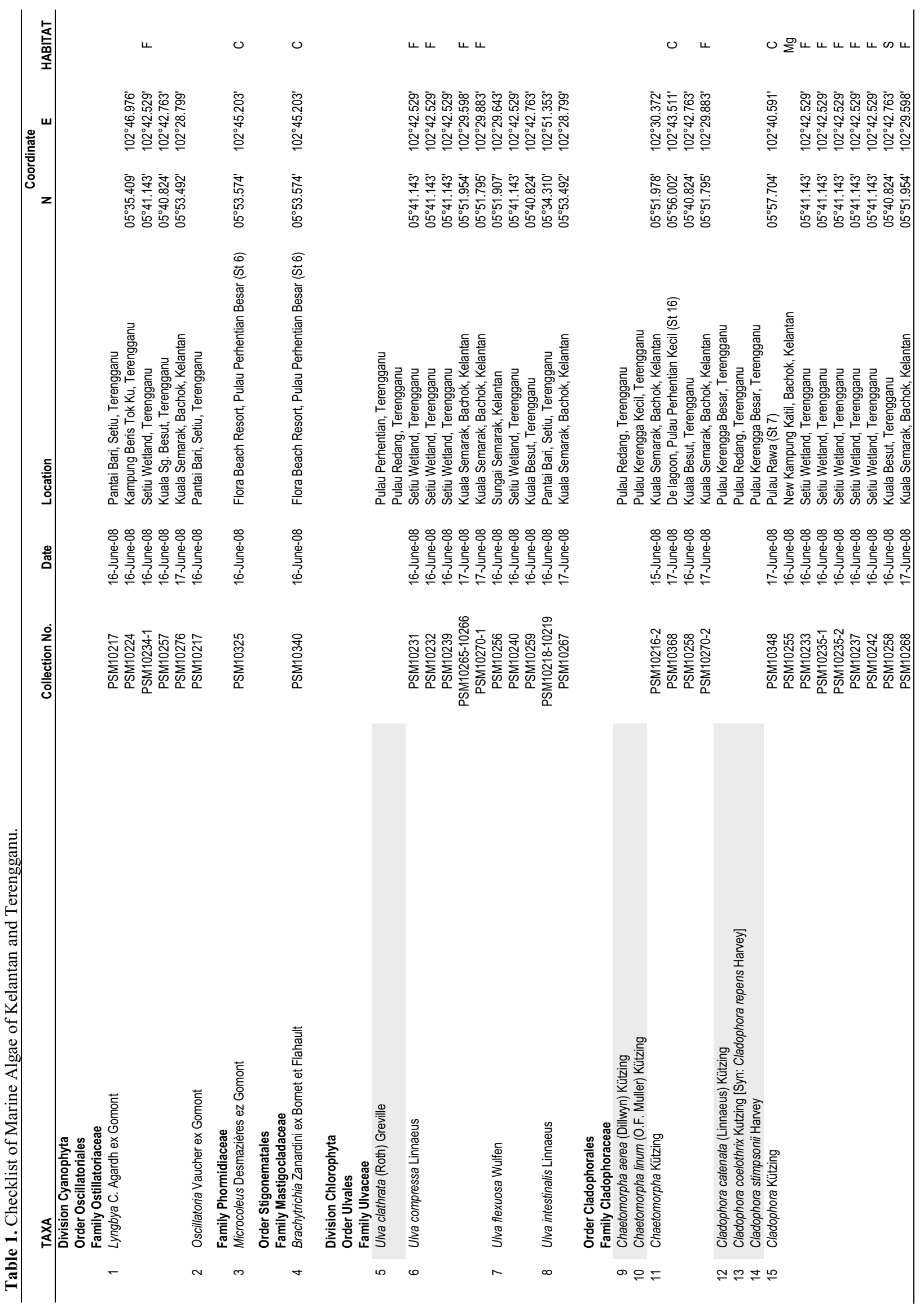




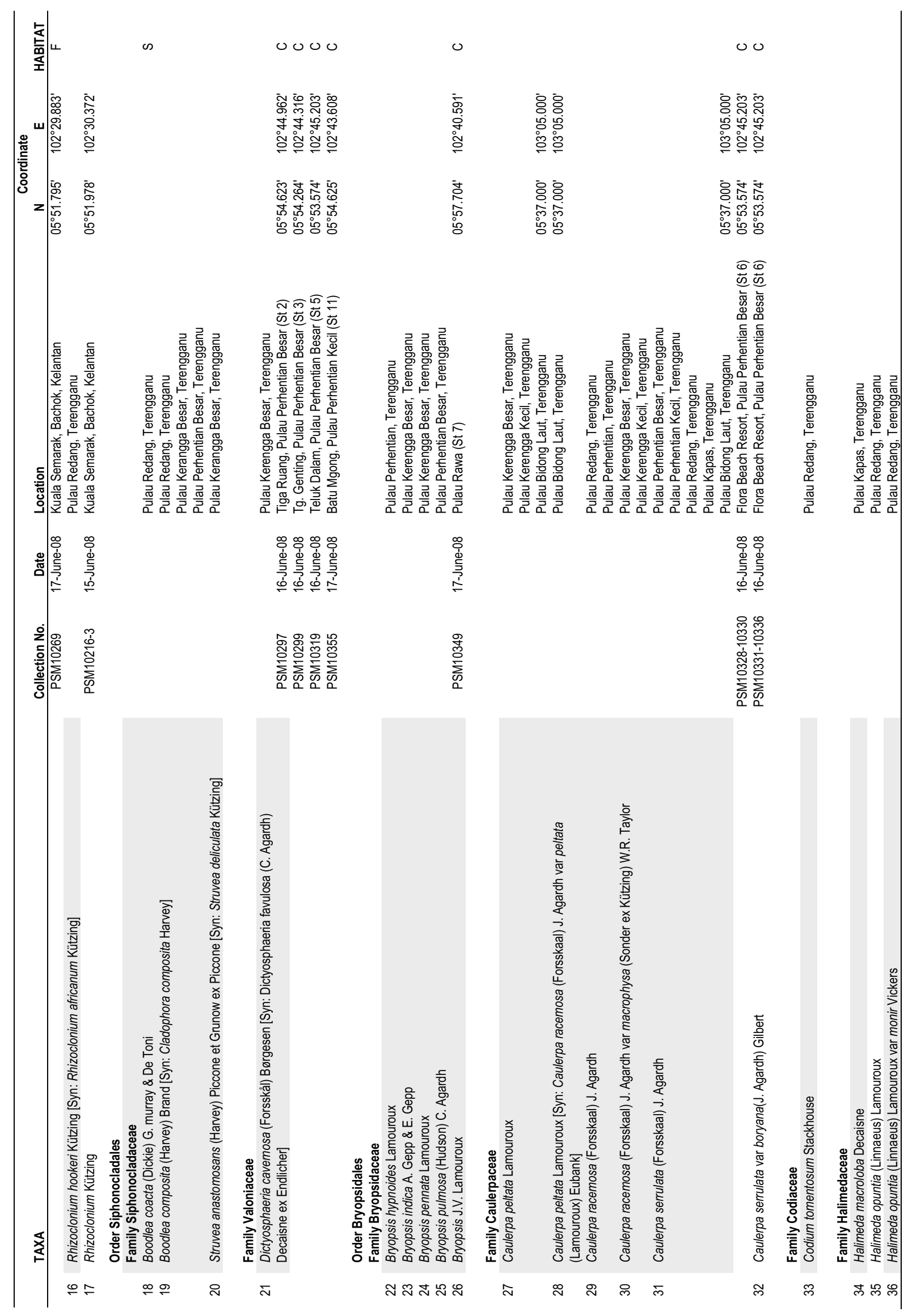




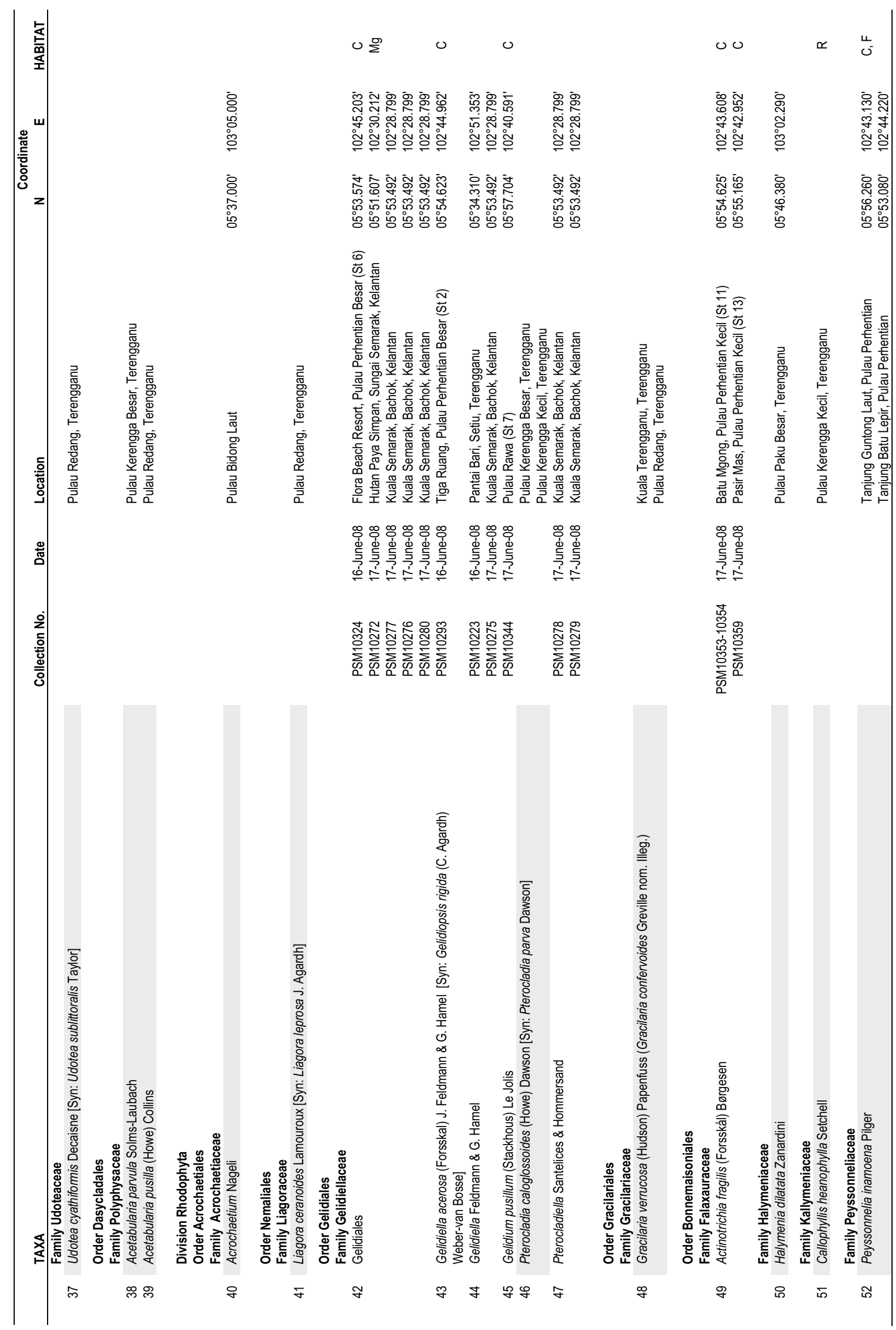









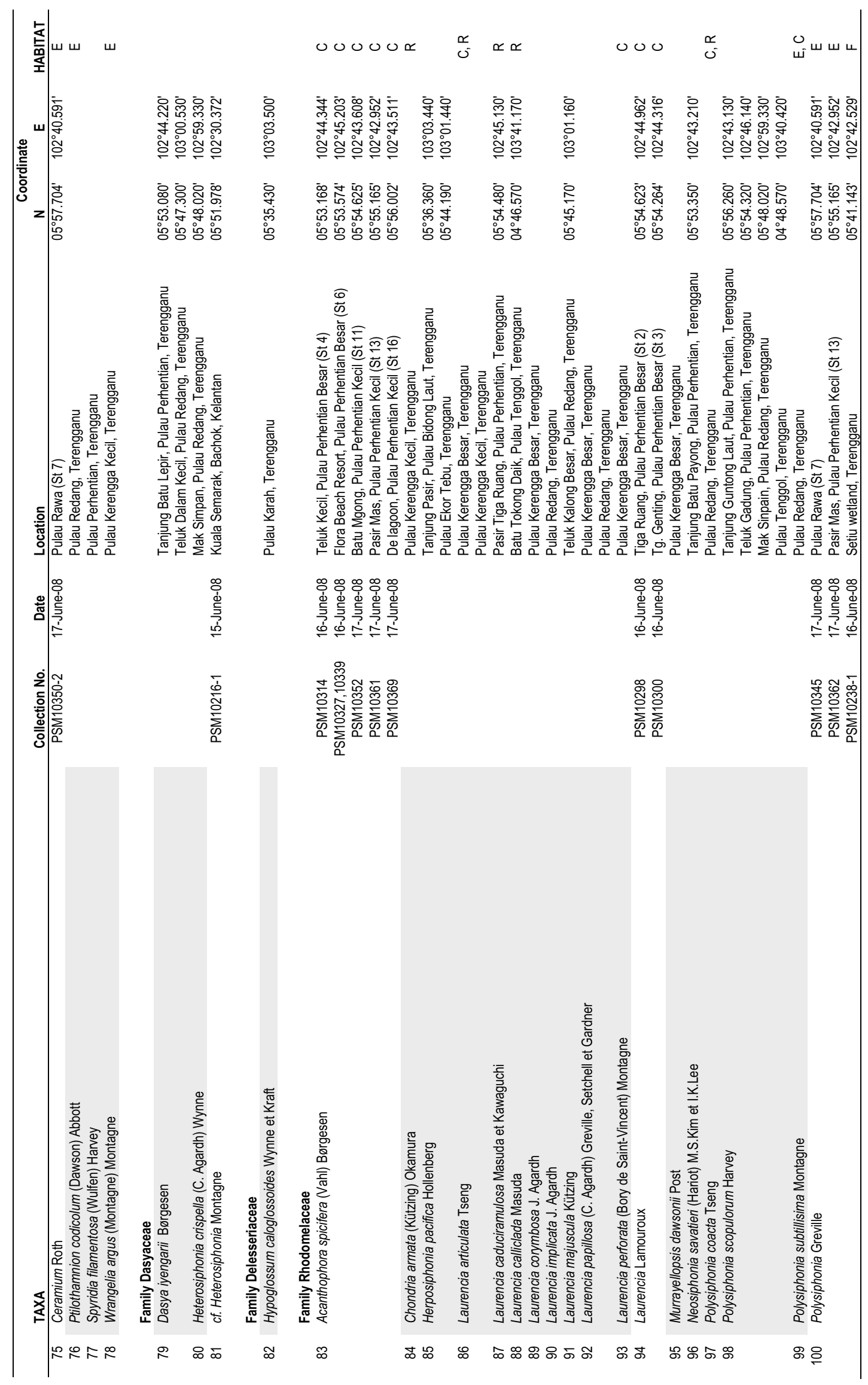




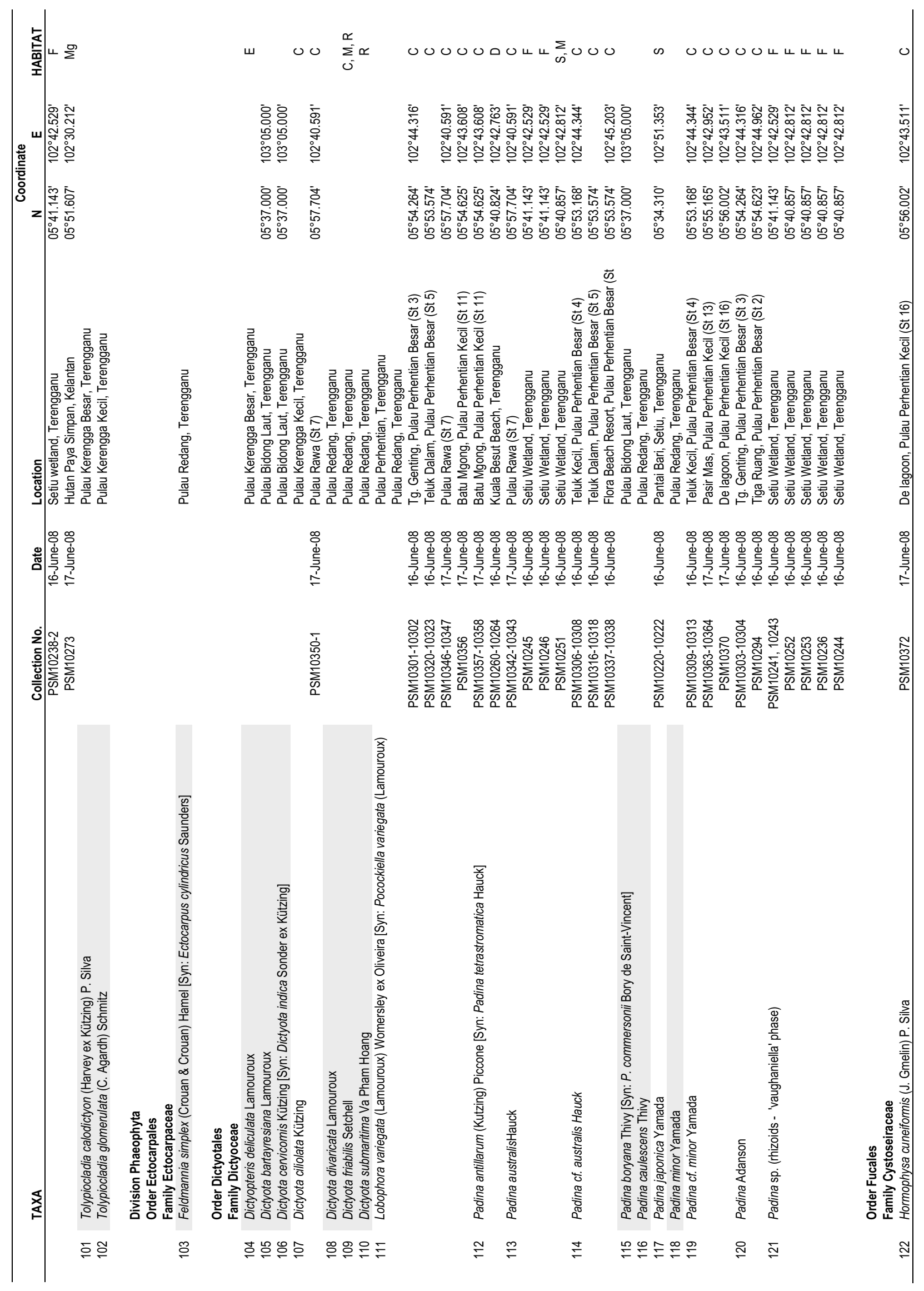




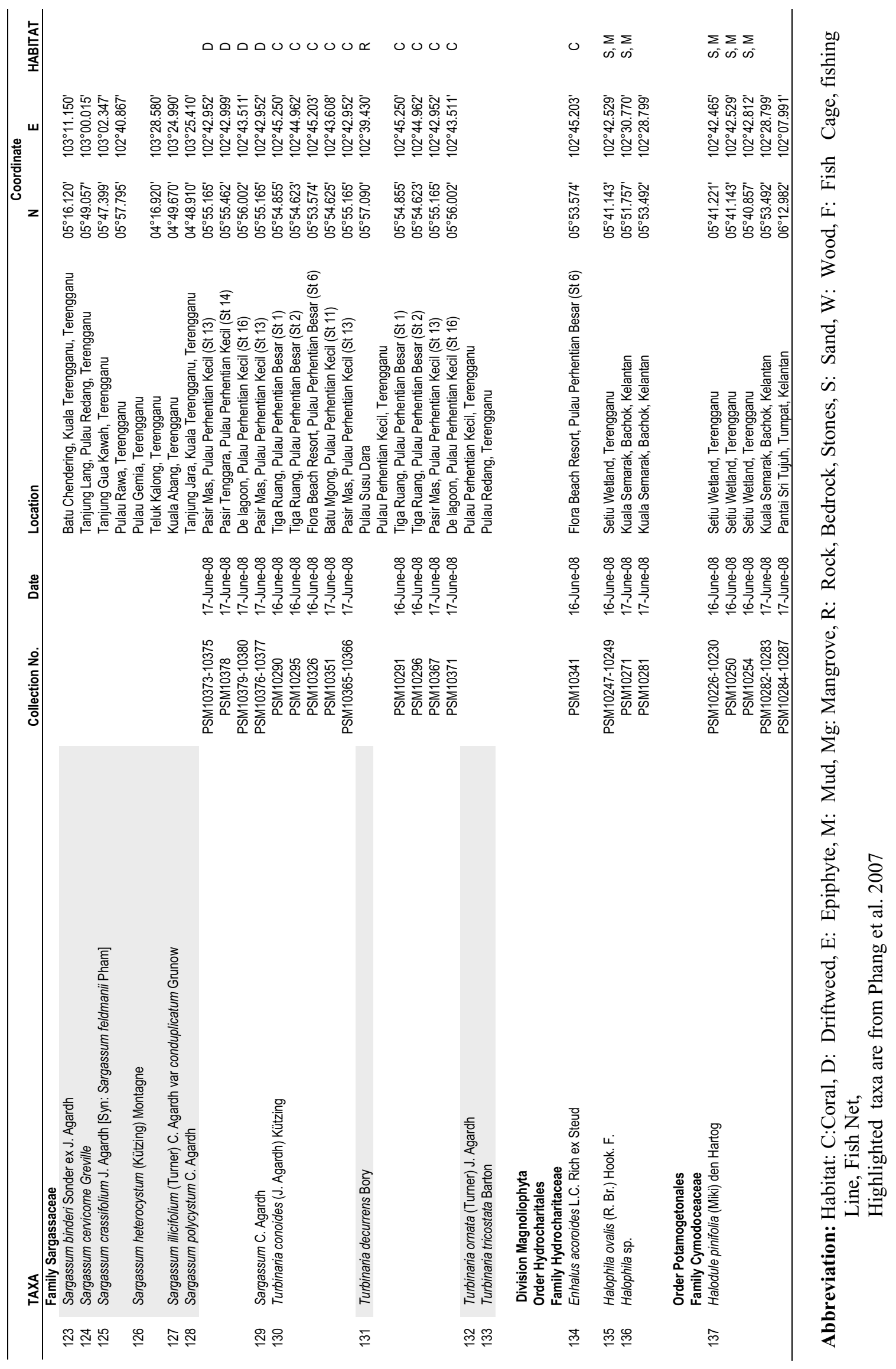




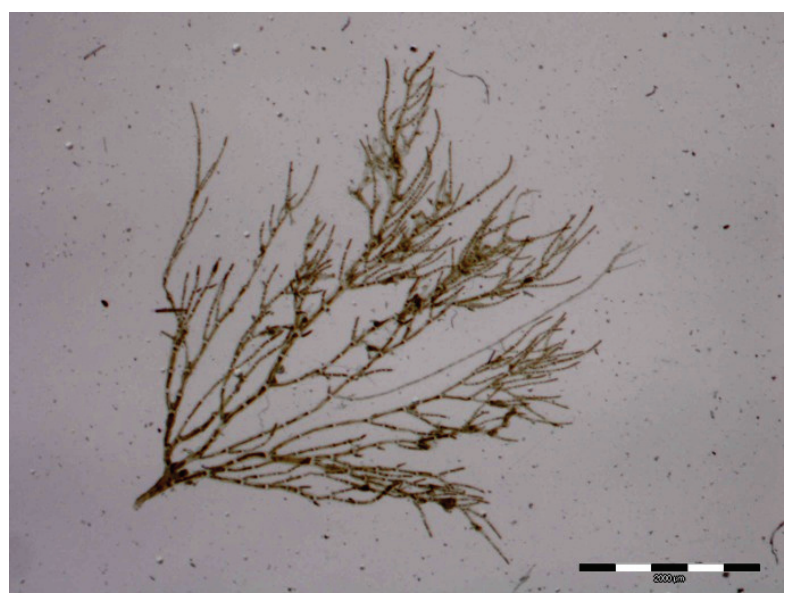

Figure 8. Cladophora

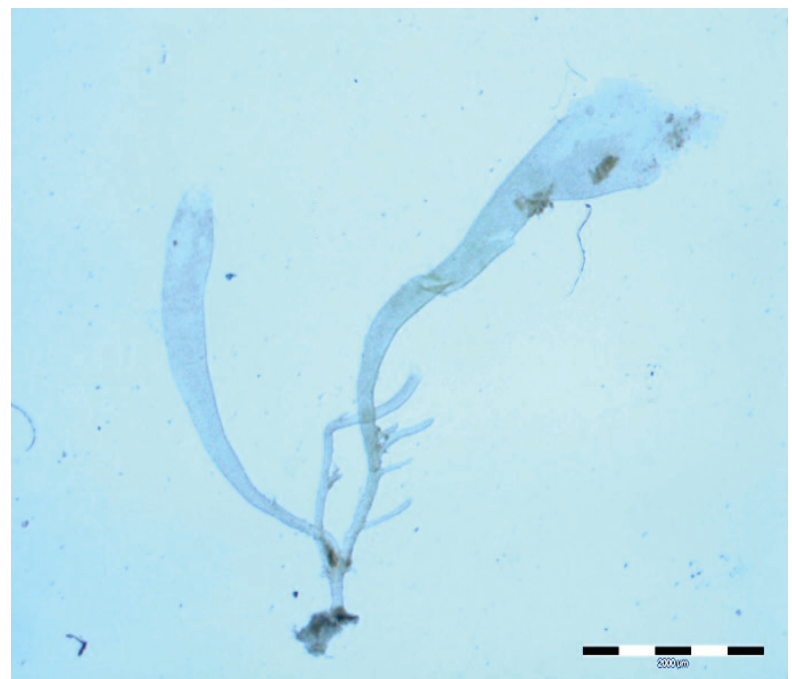

Figure 10. Ulva flexuosa

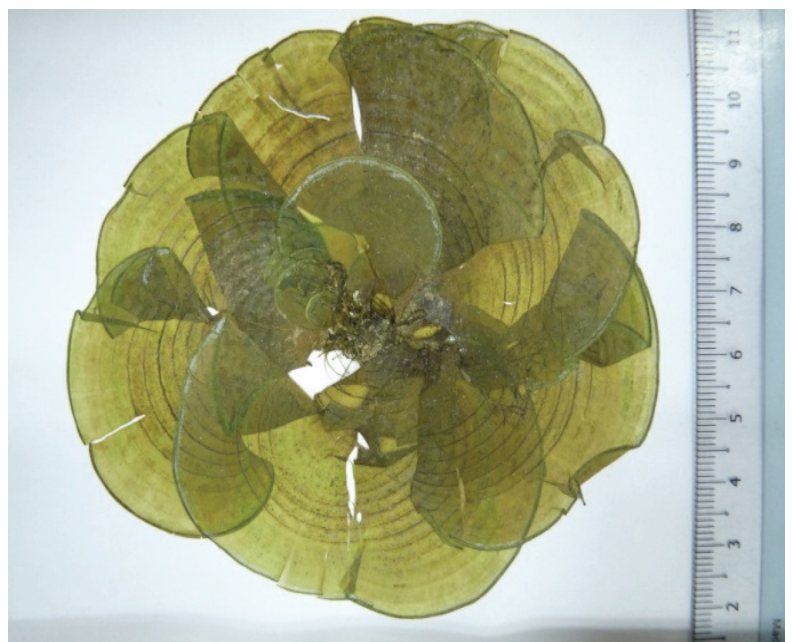

Figure 12. Padina australis (Herbarium)

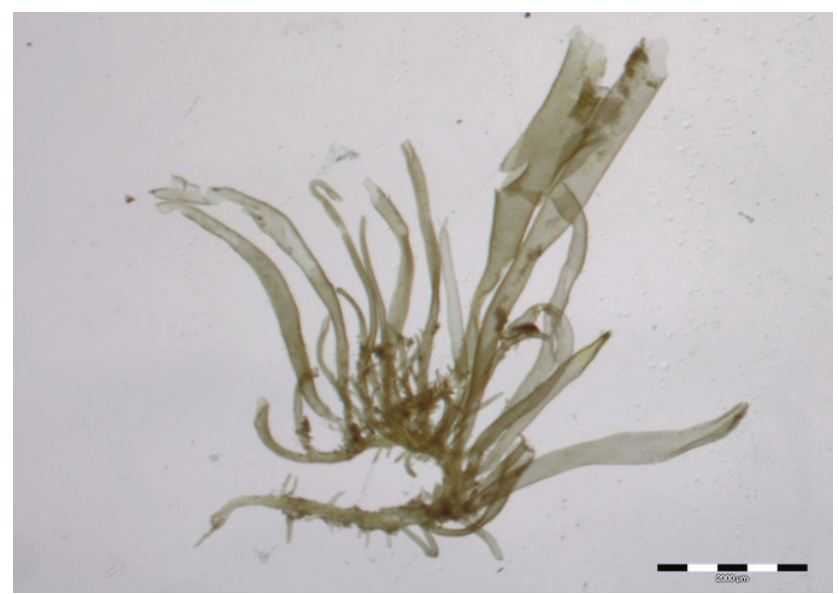

Figure 9. Ulva compressa

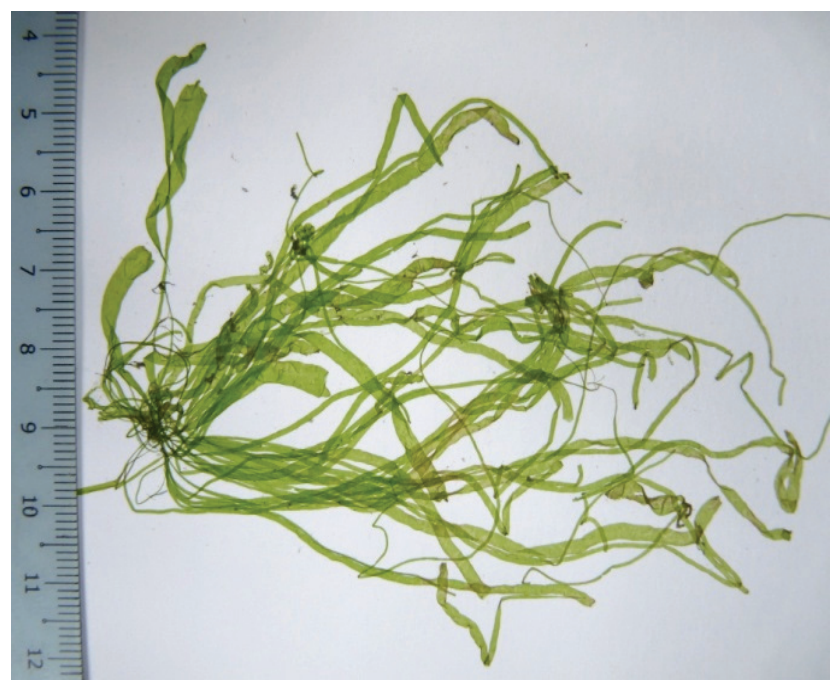

Figure 11. Ulva intestinalis

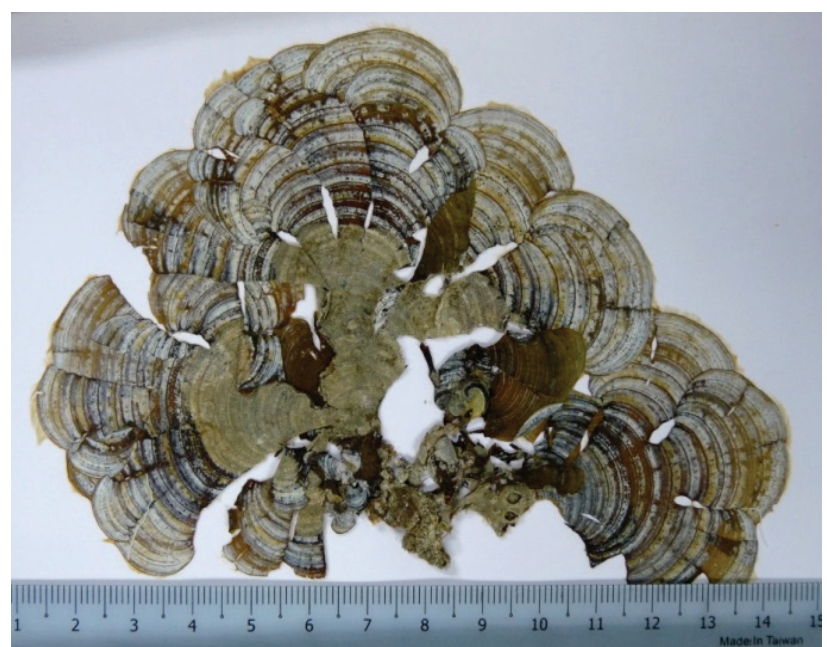

Figure 13. Padina japonica (Herbarium). 


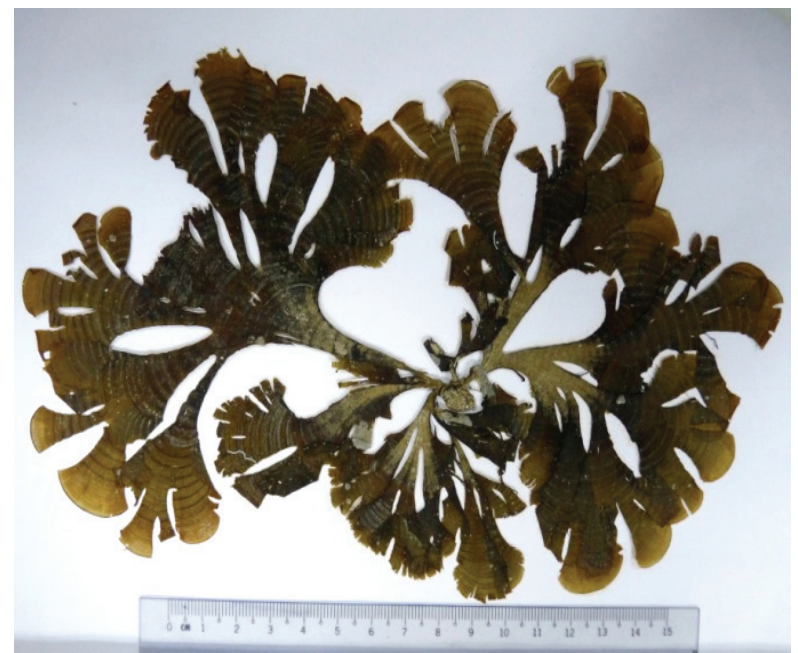

Figure 14. Padina tetrastromatica (Herbarium)

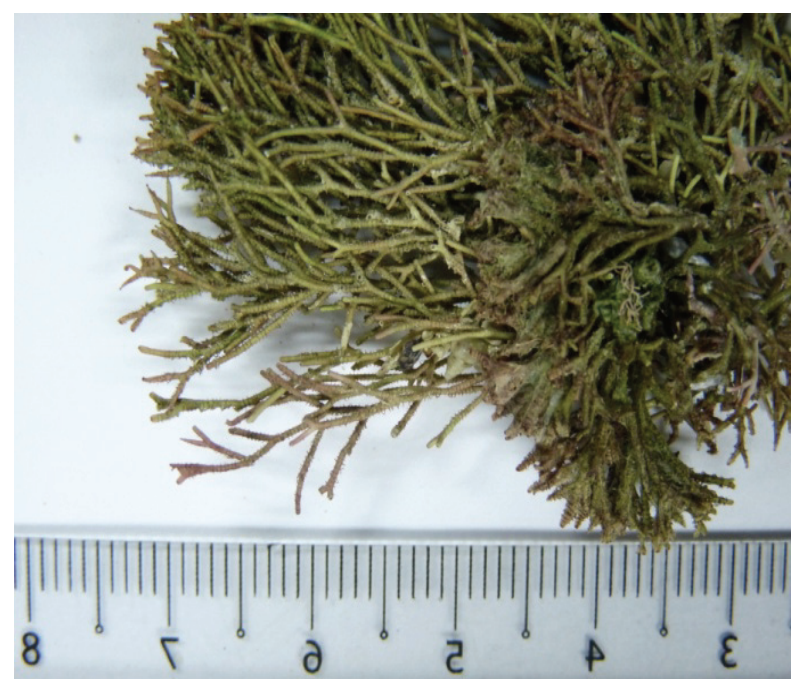

Figure 16. Actinotrichia fragilis (Herbarium)

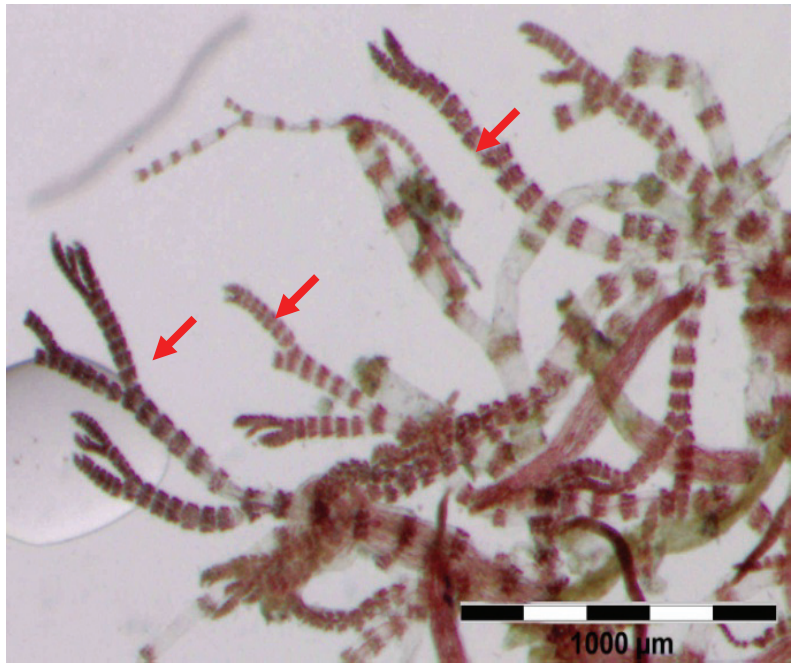

Figure 18. Ceramium

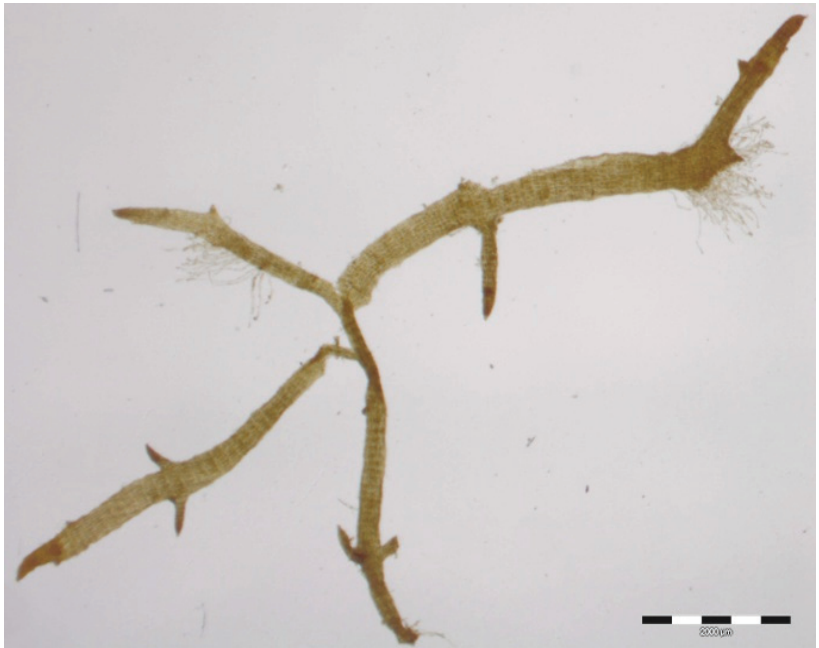

Figure 15. Padina rhizoids (Vaughaniella phase)

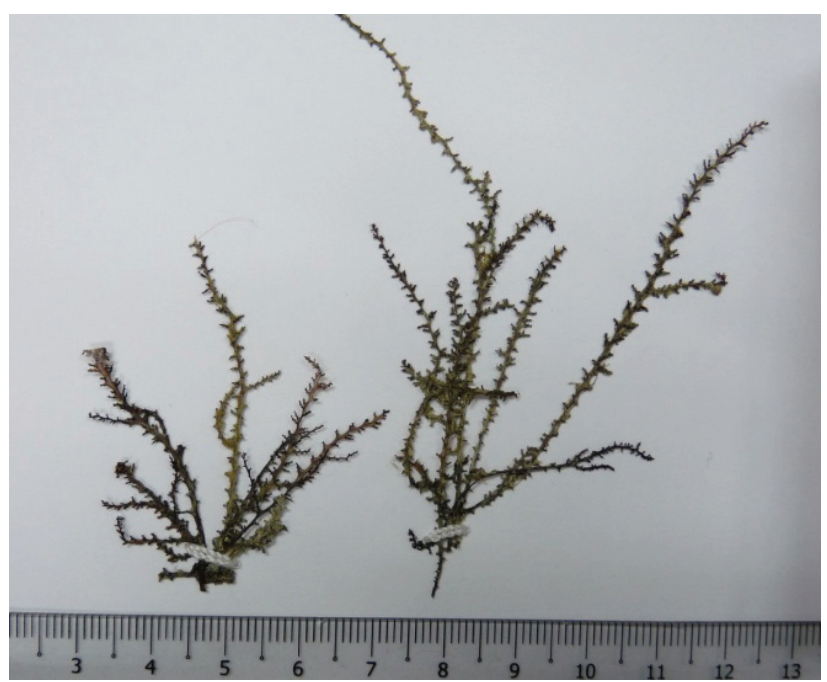

Figure 17. Acanthophora spicifera (Herbarium)

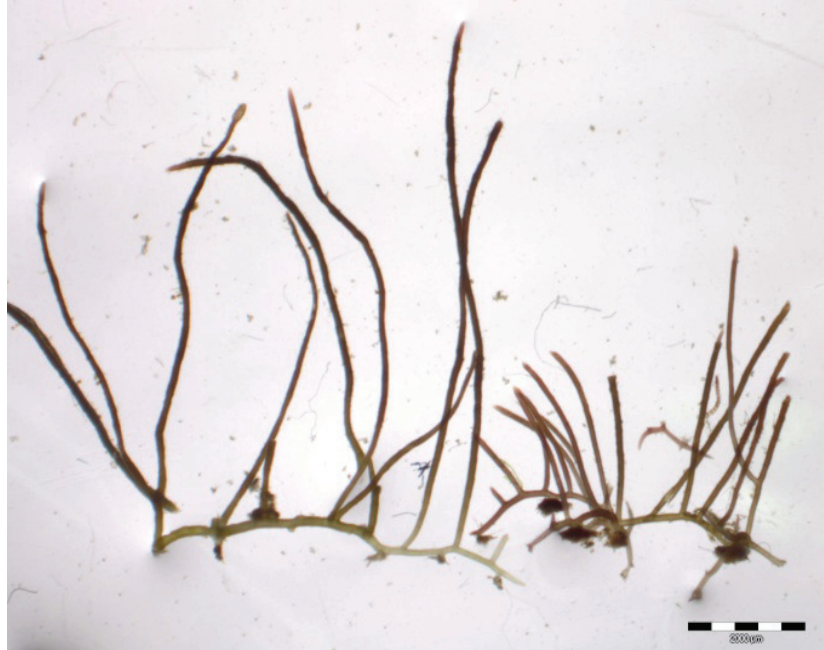

Figure 19. Gelidiella 


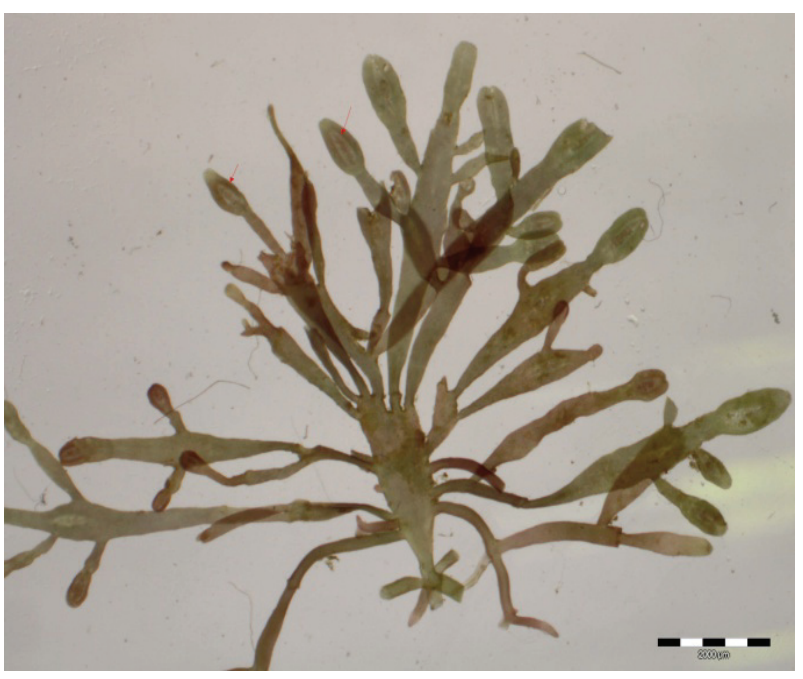

Figure 20. Pterocladiella (New record for Malaysia)

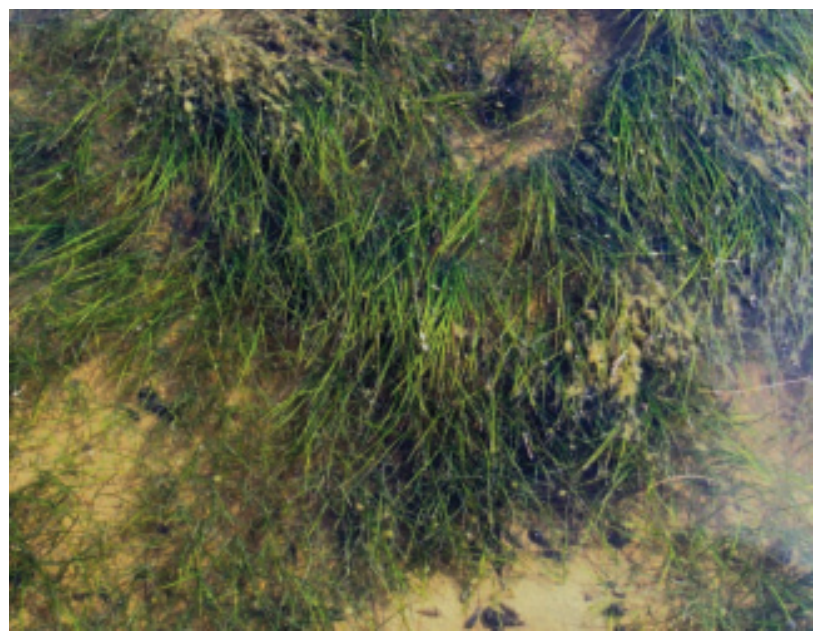

Figure 22. Halodule pinifolia

The diversity (132 taxa) of marine algae reported for Kelantan and Terengganu in this paper is higher than that reported for the Pulau Tioman group of islands (98 taxa) also located in the South China Sea, and for the Pulau Perak, Pulau Jarak and Sembilan islands (66 taxa) which are located in the Straits of Malacca. Most of the taxa for Kelantan and Terengganu in this checklist are from published records; low species diversity as well as low abundance was observed during this survey. Lack of ecological and phenological data of tropical marine algae especially that from Malaysia, make it difficult to explain the low abundance.

Of the marine algae reported for Kelantan and Terengganu, some including Ulva, Caulerpa,

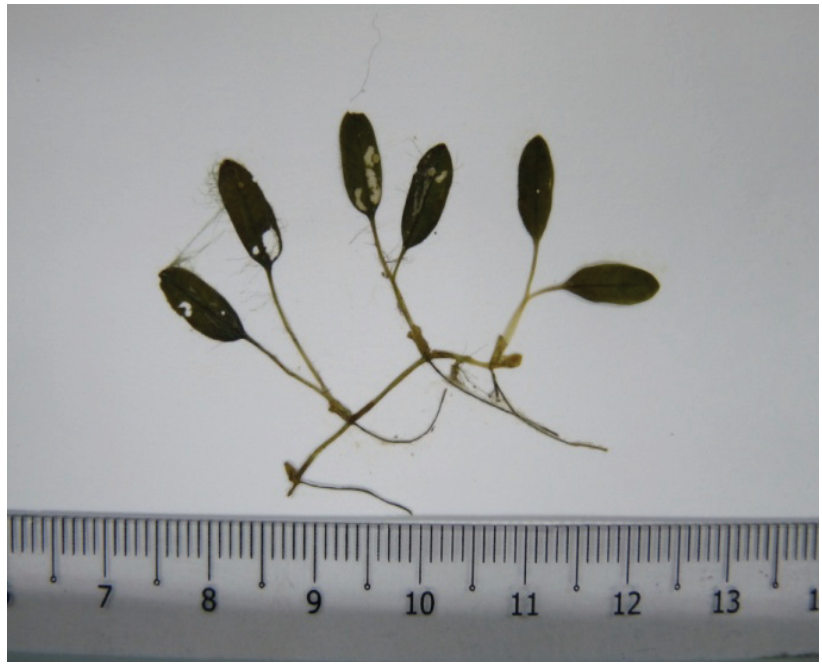

Figure 21. Halophila ovalis (Herbarium)

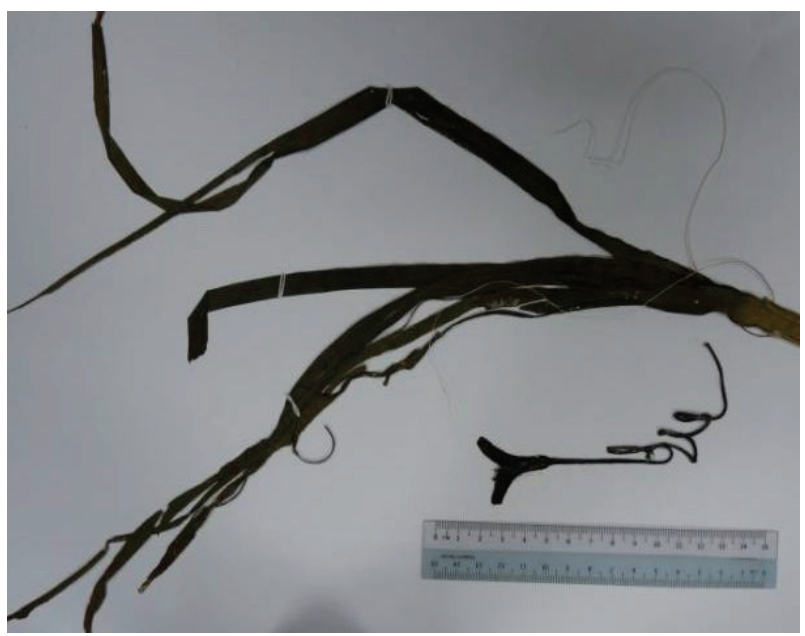

Figure 23. Enhalus acoroides (Herbarium)

Gracilaria, Hypnea, Acanthophora, Laurencia and Sargassum, have economic importance and may be considered for cultivation.

In the Algae Research Laboratory, University of Malaya, research on the molecular taxonomy and phylogenetics of Malaysia seaweeds, specifically on Gracilaria, Caulerpa, Sargassum, Gelidiales and crustose algae are on-going. Selected genetic markers are used for unraveling taxonomic confusion as well as to understand the genetic diversity and evolutionary relationships amongst the Malaysian marine algae (Yow et al. 2009, Wong et al. 2007, Lim et al. 2007, and Wong et al. 2004). 


\section{ACKNOWLEDGEMENTS}

Acknowledgements are due to Prof. Dr. Chong Ving Ching who organized this expedition, Dr. Sasekumar, Dr. Azhar Hussin and Serena Rahman for assistance during the survey; the Fisheries Department and Marine Park Department for the permission to conduct the survey, and financial assistance from the Forestry Research Institute of Malaysia (FRIM Tropical Forest Biodiversity Centre, Grant No: 20300202030), MONRE; the Ministry of Education, and the Bachok Research Grant (Grant No: FS300/2008A); the University of Malaya Research Grants (Grant No: FQ008/2007A); Malaysian Toray Science Foundation (Grant No: 66-02-03-0701); Vote PJP (Grant No: FS315/2008A). Thanks also to Jelveh Sohrabipour for assistance in confirming some of the Gelidiales.

\section{REFERENCES}

1. Lim PE, Sakaguchi M, Hanyuda T, Kogame K, Phang SM \& Kawai H. 2007. Molecular phylogeny of crustose brown algae (Ralfsiales, Phaeophyceae) inferred from $r b c \mathrm{~L}$ sequences resulting in the proposal for Neoralfsiaceae fam. nov. Phycologia 46(4): 456-466.

2. Phang, S.M., 1998. The seaweed resources of Malaysia. In: A.T. Critchley and M. Ohno (eds.) Seaweed Resources of the World, pp79-91. Japan International Cooperation Agency.

3. Phang S.M., Wong C.L., Lim P.E, Y.H.Y. \& Chan C.X., 2005. Seaweed Diversity of Langkawi with emphasis on Northeast Langkawi. Malaysian J. Science 24: 77-94

4. Phang, S.M., 2006. Seaweed Resources in Malaysia: Current status and future prospects. Aquatic Ecosystem Health \& Management 9(2): 185-202

5. Phang S.M., Wong C.L., Lim P.E., Ooi J.L.S., Gan S.Y., Melor Ismail, Yeong H.Y. \& Emienour Muzalina Mustafa. 2007. Seaweed Diversity in Malaysia. In: Chua L.S.L., Kirton L.G., \& Saw L.G., (eds) Status of Biological Diversity in Malaysia and Threat Assessment of Plant Species in Malaysia. Forest Research Institute Malaysia. p. 185-210

6. Phang S.M., Lim P.E., Ooi L.S.J., Yeong H.Y., Ng W.S., and Küpper F.C. 2008a. Marine algae of Perak Island, Jarak Island and the Sembilan Group of Islands in the Straits of Malacca. Malaysia J. Science, 27 (3): 47-60

7. Phang S.M., Wong C.L, Yeong H.Y. and Masuda M. 2008b. Marine algae of Pulau Tioman, East Coast Peninsular Malaysia. In Phang S.M., Amri A.Y., Ooi L.S.J. and Mydin
HAJ (eds). Natural history of the Pulau Tioman group of Islands. Institute of Ocean and Earth Sciences, University of Malaya Monograph Series 1. p19 - 34.

8. Wong C.L., Gan S.Y. \& Phang S.M., 2004. Morphological and molecular characterisation and differentiation of Sargassum baccularia and S. polycystum (Phaeophyta). J. appl. Phycol. 16: 439-445

9. Wong C.L., Ng S.M. \& Phang S.M., 2007. Use of RAPD in differentiation of $€$ selected species of Sargassum (Sargassaceae, Phaeophyta). J. Appl. Phycol. 19(6): 771-781

10. Yow Y.Y., Lim P.E. \& Phang S.M. 2009. Genetic diversity of Malaysian Gracilaria changii and Gracilaria edulis. Phycologia 48(4): 75-76 (Abstract) 